The European Journal of Finance, 2016

http://dx.doi.org/10.1080/1351847X.2016.1239585

Routledge
Taylor \& Francis Group

\title{
Pension fund manager skills over the economic cycle: the (non-)specialization cost
}

\author{
Mercedes Alda* \\ Accounting and Finance Department, University of Zaragoza, Zaragoza, Spain
}

(Received 9 February 2016; final version received 15 September 2016)

\begin{abstract}
We study whether pension fund managers, as professionals of important social and financial products, are able to add value for their clients and adapt to economic changes. To this end, we analyze the performance and skills (market timing and stock picking) over the economic cycle from both pension fund and manager perspectives. This double analysis allows examining whether skills reside in managers and/or funds and control for manager substitutions. Despite the long-term nature of pension funds, we find that both fund and manager skills vary with market conditions, showing better evidence of stock-picking in booms, and of market timing in recessions. Nonetheless, top (bottom) funds and managers exhibit both (incorrect) skills in booms and in recessions. Some of the top (bottom) funds and managers are the best (worst) in both abilities in the same periods, but not in different periods, showing that not all managers have the ability to adapt to market conditions. Additionally, managers with limited skills tend to specialize because diversification requires multi-task skills and the non-specialization of these managers usually results in incorrect skills.
\end{abstract}

Keywords: cycles; managers; market-timing; pension fund; skill; stock-picking

JEL Codes: G11; G12; G23

\section{Introduction}

One of the primary concerns of pension fund participants and beneficiaries is to know whether the management of their future retirement savings is producing optimal results; that is to say, whether managers are adding value to the investments, and in what manner. The ability to add value is especially important for pension fund participants and beneficiaries, since pension funds are professionally managed. Participants often raise three questions about management behavior: in which assets do managers invest/disinvest their savings, when do they do so, and what is the result; that is, whether they present stock-picking and market timing abilities, and what level of performance is achieved.

A correct stock-picking ability means holding more of the stocks with higher realized returns, while correct market timing means increasing holdings when market returns are high, increasing exposure to the market portfolio. The financial literature shows mixed evidence of these skills in several financial products, finding more evidence of stock-picking ability than of market timing, and contradictory results between both abilities (Ferson et al. 1996; Graham et al. 1996; Daniel et al. 1997; Becker et al. 1999; Lee 1999; Bollen et al. 2001; Fung et al. 2002; Ferson and Quian 2004; Avramov et al. 2006; Kacperczyk et al. 2007; Mamaysky et al. 2008; or Elton et al. 2012). With regard to pension funds, results are in this same line; positive stock-picking and negative market timing (Coggin et al. 1993; Thomas et al. 2001), negative stock-picking

*Email: malda@unizar.es

(C) 2016 Informa UK Limited, trading as Taylor \& Francis Group 
and market timing (Blake et al. 1999), and absence of both (Koh et al. 2010; Woodward and Brooks 2010).

Although certain studies find some positive selectivity and timing abilities (Glassman et al. 2006; Ammann and Zingg 2008), or only positive market timing (Busse and Busse 1999; Laplante 2003; Jiang et al. 2007; Raju and Rao 2009; Chen et al. 2010; Neuhierl et al. 2011), what is striking is the broad evidence of negative market timing (Knigge, Nowak, and Schmidt 2004; Schmidt, Nowak, and Knigge 2004; Boney, Comer, and Kelly 2005; Christensen 2005; Abdel-Kader et al. 2007).

This wide range of results is justified, variously, as depending on different samples, different time horizons, frequency data (Bollen et al. 2001), or the model applied. With regard to the last aspect, the models most often applied are returns-based models (Treynor and Mazuy 1966; Merton, Henriksson, and Merton 1981; among others). However, these models present several biases, such as no consideration of conditional frameworks (Ferson et al. 1996), or no inclusion of flow-return relationships (Edelen and Warner 1999). On the other hand, measures based on portfolio holdings are less common, given the difficulties of finding suitable data, but they do allow us to study specific securities at different moments.

A recent and interesting explanation of scarce market timing has been provided by Kacperczyk, Nieuwerburgh, and Veldkam $(2011,2014)$, who indicate that skills depend on economic conditions. Kacperczyk, Nieuwerburgh, and Veldkam (2011) hold that managers' skills come from the anticipation of micro- and macro-fundamentals; that is, managers should anticipate both the specific evolution of stocks (micro) and the economic evolution (macro). However, micro- and macro-fundamentals can move opposite to each other at times, so finding a balance between them may suppose the appearance of varying skills. Some studies find a relationship between fund performance and the business cycle (Ferson et al. 1996; Christopherson et al. 1998; Moskowitz and Moskowitz 2000; Glode and Glode 2011; Kosowski and Kosowski 2011) but do not analyze the link between skills and cycles. As a consequence, the absence of skills found in prior works could be because those analyses do not examine skills in different economic phases. Specifically, Kacperczyk et al. (2014) find stock-picking skills in booms and market timing in recessions. This suggests that managers specialize in one task; that is, they focus on one skill, according to market conditions. The basis of this behavior can reside in the fact that managers should balance their holdings to achieve both abilities, but the same portfolio change might produce correct stock picking and incorrect timing, or vice versa. Therefore, developing correct timing and selectivity at the same time can be difficult, and managers decide to focus their effort on the most feasible skill, according to market conditions.

The pioneer work of Kacperczyk et al. (2014) shows a fund level analysis; that is, funds exhibit different skills over economic periods. Consequently, their results are produced by several managers. Managers do not usually work long periods in a fund, so one manager may not run the same fund during recessions and booms. The fund level analysis may imply that abilities reside in funds, and adaptive skills are because funds correctly replace managers over economic cycles trying to provide their clients optimal results over time and, accordingly, their clients are able to identify superior funds. Furthermore, the use of funds as measuring unit might also mean that the know-how is embedded in the fund, and the fund culture or the specific fund characteristics help to produce adaptive skills to the successive managers. The last statement is in line with the current debate that tries to clarify whether skills reside in funds or managers.

In order to examine whether managers do vary their skills during recessions and booms, a manager level study should be done. In this work, we apply both analyses (pension fund and 
manager levels) to study whether funds and managers vary their skills over time and shed some light in the source-skill debate, clarifying if skills are inherent in funds, managers, or both.

Additionally, we evaluate whether pension fund managers are able to develop both skills simultaneously (skill diversification), or develop different skills according to the economic conditions (skill specialization). This issue can be especially important in pension funds, because they are associated with long-term investments, and pension fund participants do not often adjust their portfolio allocations (Sialm et al. 2015). Consequently, economic cycles may not influence pension fund managers' selectivity and timing skills, unlike other institutional managers. To measure these skills, we apply the stock-picking and market timing measures developed by Kacperczyk et al. (2014), considering funds' portfolio weights. We find that pension funds and managers present better market timing in booms and stock-picking in recessions. As a result, both pension funds and managers vary their skills with economic conditions, despite the long-term nature of the pension funds.

Third, we analyze whether managers with different portfolio betas develop differential skills during economic cycles. The importance of the stock betas in portfolio holding is another important aspect of management. Stock betas evolve with economic conditions (Fabozzi and Francis 1977, 1979; Spiceland et al. 1983; Bhardwaj et al. 1993; Clinebell, Squires, and Stevens 1993; Woodward et al. 2009), so portfolio betas are not constant over time (Bollerslev et al. 1988; Evans and EVANS 1994; Lewellen et al. 2006; Kizys et al. 2011, among others). These movements are important when equity managers balance their portfolios to adjust their market exposure and develop correct selectivity and timing skills. The balance can be especially difficult when the market and certain portfolio stocks present opposite behaviors (negative market betas), because managers cannot exercise both abilities simultaneously. Our results show that funds with different betas exhibit different patterns. Managers time carefully when markets decline, or are managing funds with inverse behavior, but overweight assets independently of their betas when markets rise.

Next, we distinguish between skillful and unskilled managers and examine manager persistence to discern skill from luck. Top funds/managers always develop both abilities, and bottom funds/managers demonstrate poor abilities during expansions and crises. With regard to persistence, we find some evidence, but not all funds and managers have the ability to adapt to market conditions, since some exhibit both skills in the same periods, but not in different periods. Moreover, we find higher performance persistence in loser managers and winner funds, showing that funds frequently substitute managers to hire good performers and dismiss poor performers.

Finally, we examine whether skill diversification and specialization is applied by skillful and limited-skill managers, respectively. We also analyze the cost of non-specialization for unskillful and limited-skill managers. We find that top managers are able to develop both skills correctly, although one skill is usually higher, showing that diversification requires multi-task skills. Therefore, multi-tasking requires time, effort and concentration on different duties that may produce the incorrect development of both skills whether unskillful or limited-skill managers do not specialize. Specifically, we find that the worst funds/managers develop both skills incorrectly, and intermediate-skilled funds/managers specialize in developing one skill correctly.

The limited evidence on this topic for pension funds and the lack of studies outside the US market using portfolio holding data lend support to an analysis of Spanish domestic equity pension funds. Although some prior works (Alda, Ferruz, and Muñoz 2010; Alda et al. 2013) study these abilities for Spanish pension funds, they do not distinguish among market conditions and use traditional returns-based models (Treynor and Mazuy 1966; Merton, Henriksson, and Merton 1981), which present several biases, as we mention before. The results of these works are in line 
with prior studies and show diverse findings. Alda, Ferruz, and Muñoz (2010) find some evidence of stock-picking and perverse market timing in Spanish pension funds investing in European equities. However, Alda et al. (2013) find correct stock-picking and market timing abilities in Spanish pension funds investing in global equities. These varied results, among other causes, may be due to different abilities with market conditions. In this work, using proper measures, we examine whether the varied prior evidence is justified by varying skills over time.

The pension fund industry in Spain is the eighth largest in the EU-25 (OECD 2014) and presents certain characteristics that make its study worthwhile. First, despite the late appearance of pension funds, in 1988, the industry in Spain has experienced outstanding growth in recent decades, amounting to more than $€ 103$ billion in assets under management, and over 9.9 million participants, by March 2016. ${ }^{1}$ Second, the investment behavior is distinctive; it increased since its creation to 2007, decreased only in 2008, 2010 and 2011, and grew again since then, despite the financial crisis. This investment pattern does not completely follow economic evolution, so management behavior could also have been different from economic conditions. Moreover, the Spanish economic situation is different from most European countries, so domestic equity pension funds are influenced by those specific conditions. Finally, pension funds represented $10 \%$ of the Spanish market capitalization ${ }^{2}$ in 2014 and, although domestic equity pension funds only represent $8.6 \%$ (INVERCO 2014) of pension fund investments, they play an important social role in the Spanish stock market.

The rest of the paper proceeds as follows. In the next section, we describe the institutional context of the Spanish pension fund industry and our data sample. Section 3 presents the methodology. Our empirical results are shown in Section 4, and we present our main conclusions in Section 5 .

\section{The Spanish pension fund market and data}

\subsection{The Spanish pension fund market: institutional context}

The Spanish pension fund industry was established in 1988 under the Pension Fund Act of 1987 (Ley 8/1987). Currently, the Royal Legislative Decree 1/2002 (Real Decreto Legislativo 1/2002) and the Royal Decree 304/2004 (Real Decreto 304/2004) regulate this industry.

The Spanish pension fund market has experienced a remarkable growth despite its late appearance with regard to other European countries, like Germany or the United Kingdom. This market is characterized by a considerable concentration and the $€ 103$ billion of assets under management (March, 2016) are managed by fifty management groups, among which, three groups control more than $50 \%$ of the market. ${ }^{3}$

Pension funds are established and ruled according to the mentioned legislation, which distinguishes three personal elements in all pension funds: sponsors, participants and beneficiaries. Sponsors are the fund founders; that is, any entity, corporation, company, firm, association, trade union, financial institution or collective that establishes the pension fund (Article 3, Royal Legislative Decree 1/2002). Participants are the members who have some contractual claim against the assets of the pension fund. Members can be active (they are working and contributing to the pension fund), passive (they are retired and receiving pension fund benefits), and deferred (members that no longer contributes but has not yet begun to receive retirement benefits). Finally, beneficiaries are individuals entitled to receive the pension fund benefits. Beneficiaries may or not be participants, since participants may make contributions on behalf of themselves or 
other beneficiaries. Therefore, participants and beneficiaries are usually the same individual and sometimes different.

In Spain, participants and sponsors cannot manage the pension fund assets, so pension fund contributions are managed professionally by a pension fund management company, which designates a manager or team for this task. Furthermore, the custody and the deposit of the assets are handled by a custodian entity, different from the management company. Therefore, an individual cannot be manager and custodian of a pension fund at the same time (Article 82, Royal Decree 304/2004). Moreover, the pension fund control and supervision are carried out by a control commission.

The assessment of the manager performance lies on the management company, being responsible for appointing the management team. Management fees are the management remuneration (main manager incentive) and vary among funds and pension fund share classes. Nonetheless, the Spanish legislation establishes a maximum management fee of $1.5 \%$ of the assets under management or $1.2 \%$ of the assets plus $9 \%$ of the results. On the other hand, the custodian entity charges a custodian fee, which cannot be higher than $0.25 \%$ of the assets under management.

\subsection{Data}

Our sample is drawn from several data sets. First, Morningstar Direct provides comprehensive information about pension fund characteristics: return, Total Net Assets (TNA), inception date, portfolio holdings (specific assets and percentage invested in each asset), and pension fund managers (names and manager history by fund). Since the holding data is available quarterly, and only a few pension funds voluntarily report them monthly, we restrict our analysis to a quarterly basis. We focus our analysis on Spanish domestic equity pension funds to analyze skills according to the Spanish market evolution, so a fund must be in accordance with the investment objective under study and invest primarily in domestic equity securities, to be included in the sample. The pension funds studied have at least $75 \%$ of their holdings in stocks. We exclude index pension funds for robustness. The resulting sample, free of survivorship bias, includes 31 distinct funds and 49 managers, with quarterly observations from December 2002 to September 2015.

The stock market information (stock price data and market index data) are obtained from Datastream database. To calculate fund returns, we link reported stock holdings and weights from Morningstar to the Datastream stock prices.

We measure recession and boom periods using the OECD-based recession indicator for Spain from the Federal Reserve Economic Data. The onset of the recession is the peak of economic activity and its end is the trough. Our aggregate sample spans 53 quarters of data from December 2002 through September 2015, among which the boom periods are June 2004-December 2007, December 2009-June 2011, and March 2013-September 2015; the recession periods are December 2002-March 2003, March 2008-September 2009, and September 2011-December 2012.

The risk-free asset, market, size, book-to-market and momentum factors are the European factors (given the geographical location of Spain) of Fama et al. (1993) and Carhart and Carhart (1997) developed by Fama and French. ${ }^{4}$

Table 1 is divided into two panels and reports summary characteristics of our sample. Panel A shows the pension fund statistics. Panel B shows the risk factor statistics distinguishing between boom and recession periods. Panel $\mathrm{C}$ shows some pension fund manager statistics for the period analyzed. 
Table 1. Summary statistics.

\begin{tabular}{|c|c|c|c|c|c|c|}
\hline & \multicolumn{2}{|c|}{ Period analyzed } & \multicolumn{2}{|c|}{ Boom periods } & \multicolumn{2}{|c|}{ Recession periods } \\
\hline & Mean & Std. Dev & Mean & Std. Dev & Mean & Std. Dev \\
\hline \multicolumn{7}{|c|}{ Panel A: Pension fund statistics } \\
\hline Number of funds & 31 & & 11 & & 20 & \\
\hline Fund return & 0.0053 & 0.0513 & 0.0076 & 0.0441 & 0.001 & 0.0623 \\
\hline TNA (in million $€$ ) & 44.4 & 83.5 & 51.7 & 94.7 & 29.3 & 49.9 \\
\hline Fund age (years) & 7.1157 & 4.6083 & 7.5154 & 4.8466 & 6.473 & 4.1177 \\
\hline Stock proportion & $81.36 \%$ & 0.3088 & $85.23 \%$ & 0.3104 & $77.50 \%$ & 0.2267 \\
\hline Portfolio beta & 0.8321 & 0.1412 & 0.849 & 0.4326 & 0.8049 & 0.4036 \\
\hline \multicolumn{7}{|c|}{ Panel B: Risk factor statistics } \\
\hline Market factor & 0.0081 & 0.0551 & 0.0093 & 0.0421 & 0.0038 & 0.0713 \\
\hline Size factor & 0.0018 & 0.0194 & 0.0026 & 0.0166 & 0.0005 & 0.0232 \\
\hline $\begin{array}{l}\text { Book-to-market } \\
\text { factor }\end{array}$ & 0.0009 & 0.0213 & 0.0001 & 0.0182 & 0.0024 & 0.0256 \\
\hline Momentum factor & 0.0067 & 0.0409 & 0.0131 & 0.0195 & -0.0036 & 0.0602 \\
\hline \multicolumn{7}{|c|}{ Panel C: Pension fund manager statistics } \\
\hline & All periods & Std. Dev & Min & Max & Booms & Recessions \\
\hline \# managers & 49 & & & & 46 & 36 \\
\hline \# teams & 13 & & & & 13 & 10 \\
\hline $\begin{array}{l}\text { \# managers running } \\
\text { several funds } \\
\text { simultaneously }\end{array}$ & 13 & & & & 12 & 5 \\
\hline \# single managers & 31 & & & & 12 & 21 \\
\hline $\begin{array}{l}\text { Average \# funds by } \\
\text { manager }\end{array}$ & 1.7674 & 1.6011 & 1 & 7 & 1.5745 & 1.3514 \\
\hline $\begin{array}{l}\text { Average \# } \\
\text { managers by } \\
\text { fund }\end{array}$ & 2.4839 & 1.4112 & 1 & 7 & 2.3125 & 1.7241 \\
\hline $\begin{array}{l}\text { Manager tenure } \\
\text { (years) }\end{array}$ & 6.1414 & 4.9039 & 0.144 & 18.475 & 6.2236 & 7.7199 \\
\hline
\end{tabular}

Notes: Table 1 is divided into two panels. Panel A shows descriptive statistics (mean and standard deviation) of the pension funds analyzed: quarterly return, quarterly TNA in million Euros, fund age (in years), the average stock proportion, and the quarterly portfolio beta for the entire period analyzed (December 2002-September 2015), in booms and in recessions. Boom periods are: June 2004-December 2007, December 2009-June 2011, and March 2013-September 2015. Recession periods are: December 2002-March 2003, March 2008-September 2009, and September 2011-December 2012. Panel B shows quarterly descriptive statistics of the risk factors: market excess return, size, book-to-market, and momentum for the period studied, in booms and in recessions. Panel C shows some descriptive statistics of the pension fund managers analyzed for the period studied, booms and recessions: number of managers (\# managers), number of teams (\# teams), number of managers running several funds simultaneously, number of single managers all period studied (\# single managers), number of funds by manager, number of managers by fund, and manager tenure (in years).

In panel A, we observe that pension funds achieve greater returns during boom periods $(0.76 \%)$ than in recessions $(0.1 \%)$. Our sample presents more funds during recessions but fund size is smaller than in booms (€27.7 million versus $€ 51.6$ million). The average fund is over 7 years old. The stock proportion is $85.23 \%$ in booms and $77.5 \%$ in recessions, showing that managers balance their portfolios to less risky assets in crises. In the same line, portfolio betas 
are higher during up periods, showing more market exposure. Panel B shows that all risk factors, except the book-to-market factor, display larger values during expansion. Panel $\mathrm{C}$ shows that the 31 pension funds studied are managed by 49 different managers and, some of them form teams, comprising 13 different teams through the period studied. We find 13 managers running several funds simultaneously throughout the period analyzed, and 31 managers are always single fund managers. We should note that some managers run funds individually certain periods and are part of teams other periods. Furthermore, several managers consecutively run some of the sample funds. The number of funds handled by manager is, on average, 1.76 funds, with a minimum of 1 fund and a maximum of 7 funds. On the other hand, the average number of managers by fund is 2.48 managers (a minimum of 1 manager and a maximum of 7 managers). The average manager tenure in a fund is 5.60 years. It is remarkable the maximum tenure (18.48 years), which shows that some managers run the same funds more time than the period analyzed. This case corresponds to a fund managed by a team of two managers. Additionally, the number of managers, teams, funds by manager and managers by fund is higher in booms than in recessions, showing that crises affect fund resources. On the contrary, the number of funds managed by one manager and the manager tenure increase in crises, indicating that funds substitute managers less frequently during recessions.

\section{Method}

\subsection{Measurement of manager skills: stock-picking and market timing}

We measure skills from both fund and manager perspectives to analyze whether skills reside in funds or managers. The results from the fund level analysis will show the skills of several managers over time; however, the results of the manager level analysis will show the skill of each individual over time.

Managers who present stock-picking and market timing skills invest in the correct assets at the right time, forming portfolios that outperform the average manager. To capture these skills, Kacperczyk et al. (2014) develop variants of the performance measures of Grinblatt et al. (1993) and Daniel et al. (1997), providing unconditional and independent portfolio-style measures. The unconditional character is given by the skill definition. Skill is the cognitive ability to process information (public or private) with limited time in order to generate a high-performance portfolio.

The stock picking ability is the skill of a manager to increase portfolio weights in a stock when the firm's realized stock return is high. The stock-picking measure (Picking ${ }_{t}^{j}$ ) determines how the fund's holdings of each stock co-move with the idiosyncratic component of the stock return, relative to the market. The picking measure is calculated as 'the product of a fund's portfolio weights in deviation from market weights and the firm-specific component of stock returns' (Kacperczyk et al. 2014):

$$
\operatorname{Picking}_{t}^{j}=\sum_{i=1}^{N^{j}}\left(w_{i, t}^{j}-w_{i, t}^{m}\right)\left(R_{t+1}^{i}-\beta_{i, t} R_{t+1}^{m}\right),
$$

where $w_{i, t}^{j}$ is stock $i$ 's value weight in the fund, which is the fraction of fund $j$ 's total assets held in risky asset $i$ at the start of time $t . w_{i, t}^{m}$ is stock $i$ 's value weight in the market portfolio, that is, the fraction of total market capitalization in asset $i . \beta_{i}$ measures the covariance of stock $i$ 's return $\left(R^{i}\right)$ with the market return $\left(R^{m}\right)$ divided by the variance of the market return. $\beta_{i, t}$ 
is computed quarterly, using daily data, from the regression model of assets $i$ 's excess returns on market excess returns. $R_{t+1}^{m}$ is the realized return between the start of period $t$ and the start of period $t+1$; therefore, the systematic component of the return is unknown at portfolio formation time. $R_{t+1}^{i}-\beta_{i, t} R_{t+1}^{m}$ and $\beta_{i, t} R_{t+1}^{m}$ are the idiosyncratic and systematic components of asset $i$ 's returns.

When fund managers are better at selecting stocks whose future idiosyncratic component $\left(R_{t+1}^{i}-\beta_{i, t} R_{t+1}^{m}\right)$ will outperform its systematic component $\left(\beta_{i, t} R_{t+1}^{m}\right)$, they will increase more the portfolio weights in those stocks than the weights of those stocks in the market portfolio. On the other hand, managers underweight stocks with low idiosyncratic returns.

Measure (1) shows the stock-picking ability at a fund level; therefore, to measure the stockpicking ability of a manager, we calculate the quarterly stock-picking skill of each fund managed by a given manager, and we then obtain the average manager skill per quarter. As a result, we capture the skill of each manager over time, taking into account the management of several funds at the same time.

A market timing skill means increasing the portfolio market exposure in periods when the realized market return is high and decreasing it when the realized market return is low. The market timing measure (Timing ${ }_{t}^{j}$ ) is 'the product of portfolio weights in deviation from market weights and the aggregate component of stock returns' (Kacperczyk et al. 2014). This measure shows how the holdings of each asset in a fund co-move with the systematic component of the stock return, relative to the market.

$$
\operatorname{Timing}_{t}^{j}=\sum_{i=1}^{N^{j}}\left(w_{i, t}^{j}-w_{i, t}^{m}\right)\left(\beta_{i, t} R_{t+1}^{m}\right) .
$$

Skillful managers will overweight stocks with higher market betas in their funds than those stocks' weights in the market portfolio when they expect market returns to increase in the next period. Therefore, a fund manager presents high timing ability when he/she overweights assets that have high betas before the market return increases. Likewise, when skillful managers expect a market decline, they underweight stocks with high betas.

Measure (2) shows the market timing of a fund, so we obtain the timing skill of each manager by calculating the quarterly market timing of each fund managed by a given manager and then determining the average manager skill per quarter.

\subsection{The (non)-specialization cost}

The management cycle variation approach explains that skills change over time because managers adapt to market conditions (Kacperczyk et al. 2014). Whether managers focus their efforts on developing one skill during recessions and another during booms, they are displaying specialization behavior. However, some managers may achieve both skills at the same time and specialization is not applied by these managers.

We then hypothesize that specialization may be a good strategy for managers with limited skills. Whether limited-skill managers want to develop timing and selectivity skills simultaneously, they should handle several tasks and pay attention to them all together, but this may blur their endeavor among different duties, and they may not be able to develop any skill correctly. In that case, managers will prefer to specialize and develop one skill instead of none. On the other hand, whether managers are able to develop both skills correctly (skillful managers), they will not be interested in specialization because this will produce a skill cost. Consequently, 
skill specialization will appear whether managers are not able to overseeing multiple tasks and choose to focus on the skill in which they possess higher capacities. Zambrana and Zapatero (2015) find that managers running several investment objective funds are better market timers, and stock-pickers are managers handling one investment objective funds. This evidence suggests that specialization may be related to manager capacities.

To determine whether managers specialize or diversify, we decompose the stock-picking (1) measure in two elements:

$\operatorname{Picking}_{t}^{j}=\sum_{i=1}^{N^{j}}\left(w_{i, t}^{j}-w_{i, t}^{m}\right)\left(R_{t+1}^{i}-\beta_{i, t} R_{t+1}^{m}\right)=\sum_{i=1}^{N^{j}}\left(w_{i, t}^{j}-w_{i, t}^{m}\right)\left(R_{t+1}^{i}\right)-\sum_{i=1}^{N^{j}}\left(w_{i, t}^{j}-w_{i, t}^{m}\right)\left(\beta_{i, t} R_{t+1}^{m}\right)$.

The first element, $\sum_{i=1}^{N^{j}}\left(w_{i, t}^{j}-w_{i, t}^{m}\right)\left(R_{t+1}^{i}\right)$, shows the differential proportion return achieved by the fund in each asset, with regard to the market portfolio, for the difference between the portfolio and market weights. The second element is the market timing measure: $\sum_{i=1}^{N^{j}}\left(w_{i, t}^{j}-w_{i, t}^{m}\right)\left(\beta_{i, t} R_{t+1}^{m}\right)$. Therefore, the stock-picking measure is:

$$
\operatorname{Picking}_{t}^{j}=\sum_{i=1}^{N^{j}}\left(w_{i, t}^{j}-w_{i, t}^{m}\right)\left(R_{t+1}^{i}\right)-\operatorname{Timing}_{t}^{j}
$$

Analyzing the different components of expression (4), we will identify whether managers specialize or diversify and their results; that is, measure (4) will help us to distinguish between skillful managers, managers with limited skills and unskillful managers. Assuming that the first element of expression (4) is positive (the fund/manager weights the stock correctly with regard to the market and future stock return) and the timing measure is positive, we can find two scenarios. First, the first positive element is greater than the positive second element, so managers develop both skills correctly. This result shows diversification and managers are dividing their efforts into two tasks and developing both correctly; nonetheless, multi-tasking supposes considerable effort and produces that one skill (stock-picking) is adversely affected (the timing element reduces the final stock-picking score). Second, whether the first element is positive and lower than the positive timing score, manager diversification produces negative selectivity. This result might be attributed to limited-skill managers, whom only develop one skill correctly, specializing in market timing.

Additionally, whether the first element is positive and the timing measure is negative, the picking measure will be positive and the negative timing score increases the picking score. Consequently, managers specialize in stock-picking.

On the other hand, whether the first element is negative (the fund/manager weights the stocks incorrectly with regard to market and future stock returns) and the timing score is positive, the picking measure will be negative (the picking score diminishes with positive timing). That is, managers specialize in market timing.

Nonetheless, whether the first element is negative and lower than the negative timing score (or the negative timing score is greater than the negative first element), the picking measure will be positive, and managers are specializing in stock-picking.

Finally, if managers with limited skills or unskillful managers do not choose specialization and diversify their efforts between both skills, they may not be able to develop none of the skills. In this case, the first element of (4) is negative and higher than the negative timing score (or the negative timing score is lower than the first element), being both negative skills. 


\section{Results}

\subsection{Skills vary over time}

We begin by analyzing the manager skills at fund and manager levels in the period studied and testing whether funds/managers exhibit/develop different skills over the economic cycle. We then examine the skills obtained, considering fund betas. Tables 2 and 3 show the results of the fund and manager analyses, respectively.

Table 2 (panel A) shows that the management of pension fund displays positive skills over the period studied (December 2002-September 2015), although the picking measure (0.0325) is larger than the timing measure (0.0227). This is consistent with the larger stock-picking evidence found in the financial literature. These results vary across market conditions. The average market timing measure across funds is positive in recessions $(0.0901)$ and negative $(-0.0195)$

Table 2. Cyclical market timing and stock-picking abilities in pension funds.

\begin{tabular}{lcrc}
\hline & Period analyzed & Booms & Recessions \\
\hline Panel A. Market timing and stock picking results & & & \\
Market-timing & 0.0227 & -0.0195 & 0.0901 \\
Stock-picking & 0.0325 & 0.0329 & 0.0317 \\
Panel B. Skills considering fund beta & & & \\
Market-timing of funds with $\beta>1$ & 0.0042 & -0.0106 & 0.0278 \\
Market-timing of funds with $0<\beta<1$ & 0.0189 & -0.0077 & 0.0614 \\
Market-timing of funds with $\beta<0$ & 0.0001 & 0.0001 & 0.0001 \\
Stock-picking of funds with $\beta>1$ & 0.0107 & 0.0165 & 0.0015 \\
Stock-picking of funds with $0<\beta<1$ & 0.0197 & 0.0142 & 0.0285 \\
Stock-picking of funds with $\beta<0$ & 0.0006 & 0.0008 & 0.0003 \\
\hline
\end{tabular}

Notes: Table 2 is divided into two panels. Panel A shows the results of market timing and stock picking measures for the pension funds studied during the period analyzed (December 2002-September 2015), in booms and in recessions. Panel B displays the same results considering the pension fund betas (higher than one, between zero and one, and lower than zero).

Table 3. Cyclical manager market timing and stock-picking abilities.

\begin{tabular}{lccc}
\hline & Period analyzed & Booms & Recessions \\
\hline Panel A. Market timing and stock picking results & & & \\
Market-timing & 0.0055 & 0.0063 & 0.0036 \\
Stock-picking & 0.0099 & 0.0142 & 0.00001 \\
Panel B Skills considering manager fund betas & & & \\
Market-timing of funds with beta $>1$ & 0.0020 & 0.0046 & -0.0040 \\
Market-timing of funds with $0<\beta<1$ & 0.0034 & 0.0025 & 0.0052 \\
Market-timing of funds with $\beta<0$ & 0.0007 & 0.0004 & 0.0021 \\
Stock-picking of funds with $\beta>1$ & 0.0031 & 0.0028 & 0.0040 \\
Stock-picking of funds with $0<\beta<1$ & 0.0052 & 0.0072 & 0.0007 \\
Stock-picking of funds with $\beta<0$ & 0.0009 & 0.0011 & -0.0002 \\
\hline
\end{tabular}

Notes: Table 3 is divided into two panels. Panel A shows the results of market timing and stock picking measures for the managers analyzed during the period of study (December 2002-September 2015), in booms and in recessions. Panel $\mathrm{B}$ displays the same results considering the manager fund betas (higher than one, between zero and one, and lower than zero). $*, * *$, and $* * *$ indicate significance at the $10 \%, 5 \%$, and $1 \%$ level, respectively. 
during booms. On the other hand, stock-picking is always positive and deteriorates in recessions (0.0317 versus 0.0329). Consistently with Kacperczyk et al. (2014), we find greater stock-picking in booms and market timing in recessions. The superior stock-picking in booms demonstrates that the different managers of the funds identify assets with high idiosyncratic returns because of the upward trend. The negative market timing during booms suggests that funds are exposed to the market incorrectly; however, they seem more cautious in recessions and underweight (overweight) high (inverse) beta stocks in the correct moment. This behavior leads us to analyze skills considering fund betas.

Panel B of Table 2 shows that funds with aggressive (higher than one) and defensive (between zero and one) betas develop positive timing in recessions (0.0278 and 0.0614) and negative timing in booms $(-0.0106$ and 0.0077$)$. Funds with inverse betas show positive timing in booms and recessions (0.0001). This shows that funds with betas above zero underweight stocks with regard to market weights in booms and recessions, displaying a conservative strategy that leads to incorrect market timing in expansion periods. Nonetheless, inverse beta funds time the market correctly and increase (decrease) market exposure in recessions (booms), according to the behavior of their portfolios.

The stock-picking results show that funds with different betas overweight (underweight) stocks with high (low) idiosyncratic returns in all economic phases. Funds with aggressive and inverse betas achieve greater picking scores in booms, funds with defensive betas display better skill in recessions, and inverse beta funds present the lowest stock-picking in both scenarios.

With regard to the manager analysis, Panel A of Table 3 draws the same conclusions as panel A of Table 2. Both skills are positive in the period analyzed, and the picking measure $(0.0099)$ is higher than the timing measure (0.0055). Furthermore, stock-picking is higher than the timing in booms and the timing is higher than the stock-picking in recessions. Nonetheless, both skills are better in boom periods, demonstrating that the fund skills are the result of several managers' skills.

Panel B of Table 3 shows some differences with panel B of Table 2. First, negative timing is only developed by managers running funds with aggressive betas in recessions, showing incorrect overweighting in crises. The other managers (running funds with defensive and inverse betas) develop better timing in recessions, as the fund level results. Furthermore, managers running funds with aggressive betas develop better picking skill in recessions, and managers of funds with defensive and inverse betas do it in booms. Consequently, the generalized higher timing found in booms in panel $\mathrm{A}$ is due to managers running funds with aggressive betas, while the higher picking in booms is produced by managers running defensive and inverse fund betas.

The dissimilar results between Tables 2 and 3 reveal that pension funds are run by several managers and teams over time. Furthermore, we find that certain results are better in the manager analysis than in the fund analysis. This may be because several of the best managers disappear from our manager sample (Kostovetsky 2010 indicates that the best managers often leave funds to work for hedge funds); however, we continuous studying the fund handled by those managers, now managed by others. Therefore, the fund results are consequence of different managers' actions, and managers are responsible for the fund skills.

\subsection{Performance analysis}

In this section, we test whether the fund performance and the manager performance vary over the business cycle. The fund and manager performances are obtained from the CAPM and 4factor models quarterly estimated for the pension funds and managers analyzed, respectively. 


\section{M. Alda}

We estimate the CAPM and 4-factor models at manager level from the quarterly manager return, which is obtained as the quarterly fund return of each fund managed by a given manager, and we then obtain the average manager return per quarter. Tables 4 and 5 display the average CAPM

Table 4. Pension fund performance analysis.

\begin{tabular}{|c|c|c|c|c|c|c|}
\hline & (1) & (2) & (3) & (4) & (5) & (6) \\
\hline Alpha & $\begin{array}{l}-0.0005 \\
(-0.97)\end{array}$ & $\begin{array}{l}0.002 * * * \\
(4.01)\end{array}$ & $\begin{array}{l}-0.0006 \\
(-1.06)\end{array}$ & $\begin{array}{l}0.0032 * * * \\
(4.78)\end{array}$ & $\begin{array}{l}-0.0014 \\
(-1.32)\end{array}$ & $\begin{array}{l}-0.0018 * * \\
(-1.98)\end{array}$ \\
\hline Market & $\begin{array}{l}0.7181 \text { *** } \\
(77.31)\end{array}$ & $\begin{array}{l}0.5701 * * * \\
(53.67)\end{array}$ & $\begin{array}{l}0.782 * * * \\
(57.19)\end{array}$ & $\begin{array}{l}0.6475 * * * \\
(42.4)\end{array}$ & $\begin{array}{l}0.6795 * * * \\
(49.44)\end{array}$ & $\begin{array}{l}0.4725^{* * * *} \\
(27.78)\end{array}$ \\
\hline Size & & $\begin{array}{l}-0.4175^{* * * *} \\
(-16.67)\end{array}$ & & $\begin{array}{l}-0.425 * * * \\
(-13.03)\end{array}$ & & $\begin{array}{l}-0.4299 * * * \\
(-10.76)\end{array}$ \\
\hline $\begin{array}{l}\text { Book-to- } \\
\text { market }\end{array}$ & & $0.4737 * * *$ & & $0.4979 * * *$ & & $0.3932 * * *$ \\
\hline & & (17.32) & & (13.51) & & (9.09) \\
\hline Momentum & & $\begin{array}{l}-0.1102 * * * \\
(-8.07)\end{array}$ & & $\begin{array}{l}-0.0972 * * * \\
(-3.31)\end{array}$ & & $\begin{array}{l}-0.2206^{* * *} \\
(-10.95)\end{array}$ \\
\hline$R^{2}$ within & 0.0081 & 0.0188 & 0.0457 & 0.0275 & 0.0134 & 0.003 \\
\hline$R^{2}$ between & 0.019 & 0.0017 & 0.1895 & 0.0122 & 0.0076 & 0.0729 \\
\hline$R^{2}$ overall & 0.0089 & 0.0083 & 0.0377 & 0.0255 & 0.0028 & 0.0132 \\
\hline
\end{tabular}

Notes: Table 4 shows the results of the CAPM and the four-factor model of Carhart and Carhart (1997) for the period analyzed (December 2002-September 2015) in models (1) and (2), respectively, for booms (models 3 and 4) and recessions (models 5 and 6 ) for the pension funds studied. $T$-statistics are reported in parentheses. All models are estimated with fixed effects. $* * *$ and $* * *$ indicate significance at the $10 \%, 5 \%$, and $1 \%$ level, respectively.

Table 5. Manger performance analysis.

\begin{tabular}{|c|c|c|c|c|c|c|}
\hline & (1) & (2) & (3) & (4) & (5) & (6) \\
\hline Alpha & $\begin{array}{l}-0.0707 * * * \\
(-17.57)\end{array}$ & $\begin{array}{l}-0.0592 * * * \\
(-13.6)\end{array}$ & $\begin{array}{l}-0.0874 * * * \\
(-15.25)\end{array}$ & $\begin{array}{l}-0.1041^{* * * *} \\
(-12.57)\end{array}$ & $\begin{array}{l}-0.0337 * * * \\
(-8.1)\end{array}$ & $\begin{array}{l}-0.0253^{* * *} \\
(-6.19)\end{array}$ \\
\hline Market & $\begin{array}{l}0.622 * * * \\
(8.01)\end{array}$ & $\begin{array}{l}0.5739 * * * \\
(6.31)\end{array}$ & $\begin{array}{l}0.3805^{* * * *} \\
(2.84)\end{array}$ & $\begin{array}{l}0.3794 * * \\
(2.21)\end{array}$ & $\begin{array}{l}0.9847 * * * \\
(15.22)\end{array}$ & $\begin{array}{l}0.9214^{* * * *} \\
(11.12)\end{array}$ \\
\hline Size & & $\begin{array}{l}-0.0381 \\
(-0.16)\end{array}$ & & $\begin{array}{l}0.9361 * * \\
(2.33)\end{array}$ & & $\begin{array}{l}-0.6695 * * * \\
(-3.42)\end{array}$ \\
\hline $\begin{array}{l}\text { Book-to- } \\
\text { market }\end{array}$ & & $-0.4553^{*}$ & & -0.5424 & & $-1.2283^{* * *}$ \\
\hline Momentum & & $\begin{array}{l}(-1.79) \\
-0.898 * * * \\
(-6.41)\end{array}$ & & $\begin{array}{c}(-1.41) \\
0.7141 * * \\
(2.01)\end{array}$ & & $\begin{array}{l}(-4.66) \\
-0.7262 * * * \\
(-6.43)\end{array}$ \\
\hline$R^{2}$ within & 0.0619 & 0.4163 & 0.5587 & 0.0332 & 0.0129 & 0.103 \\
\hline $\begin{array}{l}R^{2} \\
\quad \text { between }\end{array}$ & 0.0014 & 0.3156 & 0.7505 & 0.0573 & 0.0165 & 0.0512 \\
\hline$R^{2} \quad$ overall & 0.0495 & 0.3947 & 0.539 & 0.0377 & 0.004 & 0.0948 \\
\hline
\end{tabular}

Notes: Table 5 shows the performance results of the managers analyzed applying the CAPM and the four-factor model of Carhart and Carhart (1997) for the period analyzed (December 2002-September 2015) in models (1) and (2), respectively, for booms (models 3 and 4) and recessions (models 5 and 6). $T$-statistics are reported in parentheses. All models are estimated with fixed effects. *, ** and *** indicate significance at the $10 \%, 5 \%$, and $1 \%$ level, respectively. 
and 4-factor model results in the period analyzed (December 2002-September 2015), booms and recessions for funds and managers, respectively. ${ }^{5}$

Table 4 shows that the CAPM alphas are negative and not significant, and the 4-factor alphas are positive in booms $(0.0032)$ and negative in recessions $(-0.0018)$. Moreover, the pension funds invest in large cap (negative size factor coefficients) and value stocks (positive bookto-market coefficients), and follow contrarian momentum strategies in booms and recessions. Consequently, pension funds present positive performance in expansions and follow the same styles, independently of the economic phases.

However, Table 5 shows that managers present generalized negative performance (negative CAPM and 4-factor alphas), invest in small cap stocks and follow momentum strategies in booms, but invest in large cap and growth stocks and follow negative momentum strategies in recessions, demonstrating differential manager investment behavior with market cycles. The absence of differential fund behavior among periods in Table 4 reveals that managers vary their investment strategies in the different funds managed, but funds are characterized by an investment objective, so managers adapt their strategies to the fund investment objectives.

\subsection{Performance and skills by quintiles}

In this section, we examine whether top and bottom funds/managers develop different behavior (performance and skills) with the economic conditions. We sort funds and managers into five quintiles based on performance (CAPM and 4-factor alphas) and skills (timing and picking). Results are collected in Tables 6 and 7 for funds and managers, respectively. Panels A and B of both tables show the performance results, panels $\mathrm{C}$ and $\mathrm{D}$ collect the timing and picking measures, and panels E-J display quintile skills considering fund betas.

In Tables 6 and 7, panel A shows that better funds/managers (first and second quintiles) always achieve positive performance, and the remaining funds (3rd, 4th and 5th quintiles) perform poorly in booms and recessions. Nonetheless, performance is lower during recessions in all quintiles. The four-factor alphas (panel B) show that better-performing funds and managers (1st and 2nd quintiles) always present positive performance, and the 1st quintile fund and manager performances are larger in booms. Third quintile managers (Table 7) also present positive and higher performance in booms; however, third and fourth quintile funds (Table 6) only perform poorly in recessions. Bottom funds and managers (5th quintile) always present negative performance, being lower in recessions. These results confirm different fund and manager performance with economic conditions, being higher in booms. Nonetheless, the top funds and best managers always outperform, while the bottom funds and worst managers underperform.

Market timing results (panel C) show that the first, second and third quintile funds and managers always present positive timing, although it is higher in recessions. The bottom timing funds and managers (5th quintile) present negative timing in both periods. In panel D (stock-picking results), while all quintile funds present better stock-picking skills in booms, the selectivity of first and third quintile managers is higher in recessions. Nevertheless, the first, second, and third quintile funds and managers present positive picking in booms and recessions, and bottom funds and managers always select stocks incorrectly.

These results still show distinctive skills with market cycles, although it is noticeable that the top funds and skillful managers develop correct timing and picking skills in all economic phases, and the bottom funds and unskillful managers are not able to time the market or pick correct stocks in booms or recessions. Additionally, the similarities between the fund and manager results suggest that the best (worst) managers usually handle the top (bottom) funds. 
Table 6. Pension fund performance and fund skill portfolio sort.

\begin{tabular}{|c|c|c|c|c|c|c|}
\hline Quintile & Average & Booms & Recessions & Average & Booms & Recessions \\
\hline \multicolumn{4}{|c|}{ Panel A. CAPM alpha } & \multicolumn{3}{|c|}{ Panel B. Four-factor model alpha } \\
\hline 1 & 0.0035 & 0.0041 & 0.0021 & 0.0103 & 0.0117 & 0.0023 \\
\hline 2 & 0.0004 & 0.0006 & 0.0000 & 0.0033 & 0.0048 & 0.0000 \\
\hline 3 & -0.0003 & -0.0004 & -0.0009 & 0.0025 & 0.0035 & -0.0007 \\
\hline 4 & -0.0009 & -0.0013 & -0.0021 & 0.0017 & 0.0027 & -0.0017 \\
\hline 5 & -0.0037 & -0.0052 & -0.0056 & -0.0023 & -0.0037 & -0.0058 \\
\hline Q1-Q5 & 0.0072 & 0.0093 & 0.0077 & 0.0126 & 0.0154 & 0.0080 \\
\hline \multicolumn{4}{|c|}{ Panel C. Market timing results } & \multicolumn{3}{|c|}{ Panel D. Stock picking results } \\
\hline 1 & 0.0262 & 0.0169 & 0.0516 & 0.0260 & 0.0321 & 0.0135 \\
\hline 2 & 0.0129 & 0.0113 & 0.0224 & 0.0091 & 0.0118 & 0.0104 \\
\hline 3 & 0.0079 & 0.0062 & 0.0068 & 0.0063 & 0.0075 & 0.0048 \\
\hline 4 & 0.0024 & 0.0040 & -0.0020 & 0.0007 & 0.0020 & -0.0010 \\
\hline 5 & -0.0096 & -0.0078 & -0.0183 & -0.0071 & -0.0047 & -0.0155 \\
\hline Q1-Q5 & 0.0358 & 0.0247 & 0.0699 & 0.0331 & 0.0368 & 0.0290 \\
\hline \multicolumn{4}{|c|}{ Panel E. Market timing of funds with $\beta>1$} & \multicolumn{3}{|c|}{ Panel F. Stock picking of funds with $\beta>1$} \\
\hline 1 & 0.0117 & 0.0101 & 0.0150 & 0.0100 & 0.0097 & 0.0104 \\
\hline 2 & 0.0070 & 0.0053 & 0.0089 & 0.0027 & 0.0039 & 0.0037 \\
\hline 3 & 0.0041 & 0.0043 & 0.0027 & 0.0019 & 0.0012 & 0.0021 \\
\hline 4 & 0.0001 & 0.0028 & -0.0032 & 0.0003 & -0.0005 & -0.0002 \\
\hline 5 & -0.0048 & -0.0013 & -0.0191 & -0.0031 & -0.0039 & -0.0034 \\
\hline Q1-Q5 & 0.0165 & 0.0114 & 0.0341 & 0.0132 & 0.0136 & 0.0138 \\
\hline \multicolumn{4}{|c|}{ Panel G. Market timing of funds with $0<\beta<1$} & \multicolumn{3}{|c|}{ Panel H. Stock picking of funds with $0<\beta<1$} \\
\hline 1 & 0.0186 & 0.0077 & 0.0267 & 0.0189 & 0.0219 & 0.0110 \\
\hline 2 & 0.0072 & 0.0050 & 0.0120 & 0.0057 & 0.0077 & 0.0079 \\
\hline 3 & 0.0038 & 0.0027 & 0.0045 & 0.0031 & 0.0035 & 0.0019 \\
\hline 4 & 0.0012 & 0.0010 & 0.0016 & 0.0008 & 0.0009 & -0.0018 \\
\hline 5 & -0.0032 & -0.0036 & -0.0040 & -0.0064 & -0.0029 & -0.0088 \\
\hline Q1-Q5 & 0.0218 & 0.0113 & 0.0307 & 0.0253 & 0.0249 & 0.0198 \\
\hline \multicolumn{4}{|c|}{ Panel I. Market timing of funds with $\beta<0$} & \multicolumn{3}{|c|}{ Panel J. Stock picking of funds with $\beta<0$} \\
\hline 1 & 0.0013 & 0.0007 & 0.0043 & 0.0019 & 0.0022 & 0.0028 \\
\hline 2 & 0.0000 & 0.0000 & 0.0000 & 0.0005 & 0.0006 & 0.0001 \\
\hline 3 & 0.0000 & 0.0000 & 0.0000 & 0.0001 & 0.0002 & 0.0000 \\
\hline 4 & 0.0000 & 0.0000 & 0.0000 & 0.0000 & 0.0000 & 0.0000 \\
\hline 5 & 0.0000 & -0.0001 & -0.0002 & -0.0003 & -0.0004 & -0.0003 \\
\hline Q1-Q5 & 0.0013 & 0.0008 & 0.0045 & 0.0022 & 0.0026 & 0.0031 \\
\hline
\end{tabular}

Notes: Table 6 is divided into 10 panels and shows the pension fund performance (panels A and B) and fund skills (panels C-J) in five quintiles for the period analyzed (December 2002-September 2015), in booms and in recessions. Quintile 1 represents the highest value and quintile 5 the lowest value. We report CAPM alphas (panel A), four-factor alphas (Panel B), market timing (panel C), stock picking (panel D), market timing and stock-picking of funds with betas higher than one (panels E and F), market timing and stock-picking of funds with betas between zero and one (panels $\mathrm{G}$ and $\mathrm{H}$ ), and market timing and stock-picking of funds with betas lower than zero (panels I and J). The last row of each panel is the difference between first and fifth quintiles.

Timing results considering fund betas (panels E, G and I) arrive at the same conclusions as in panel C. Nonetheless, the funds with inverse betas (second, third and fourth quintile of Panel I, Table 6) barely present timing abilities (with measures close to zero) and managers running funds with aggressive betas (panel E of Table 7) achieve higher timing in booms.

On the other hand, stock-timing fund results (panels F, H and J, Table 6) show that funds with aggressive betas (panel F) present higher selectivity skills in recessions (except 2nd quintile 
Table 7. Manager performance and manager skill portfolio sort.

\begin{tabular}{|c|c|c|c|c|c|c|}
\hline Quintile & Average & Booms & Recessions & Average & Booms & Recessions \\
\hline \multicolumn{4}{|c|}{ Panel A. CAPM alpha } & \multicolumn{3}{|c|}{ Panel B. Four-factor model alpha } \\
\hline 1 & 0.0325 & 0.0352 & 0.0265 & 0.0590 & 0.0595 & 0.0585 \\
\hline 2 & 0.0061 & 0.0063 & 0.0058 & 0.0257 & 0.0234 & 0.0282 \\
\hline 3 & -0.0033 & -0.0036 & -0.0022 & 0.0055 & 0.0057 & 0.0051 \\
\hline 4 & -0.0136 & -0.0131 & -0.0149 & -0.0085 & -0.0083 & -0.0095 \\
\hline 5 & -0.0521 & -0.0499 & -0.0536 & -0.0408 & -0.0309 & -0.0585 \\
\hline Q1-Q5 & 0.0846 & 0.0851 & 0.0800 & 0.0998 & 0.0903 & 0.1171 \\
\hline \multicolumn{4}{|c|}{ Panel C. Market timing results } & \multicolumn{3}{|c|}{ Panel D. Stock picking results } \\
\hline 1 & 0.0658 & 0.0572 & 0.0815 & 0.0974 & 0.0907 & 0.1088 \\
\hline 2 & 0.0247 & 0.0250 & 0.0240 & 0.0267 & 0.0268 & 0.0262 \\
\hline 3 & 0.0086 & 0.0079 & 0.0116 & 0.0064 & 0.0063 & 0.0066 \\
\hline 4 & -0.0059 & -0.0060 & -0.0056 & -0.0073 & -0.0073 & -0.0076 \\
\hline 5 & -0.0635 & -0.0509 & -0.0845 & -0.0725 & -0.0558 & -0.0883 \\
\hline Q1-Q5 & 0.1293 & 0.1081 & 0.1660 & 0.1699 & 0.1464 & 0.1971 \\
\hline \multicolumn{4}{|c|}{ Panel E. Market timing of funds with $\beta>1$} & \multicolumn{3}{|c|}{ Panel F. Stock picking of funds with $\beta>1$} \\
\hline 1 & 0.0329 & 0.0332 & 0.0323 & 0.0338 & 0.0313 & 0.0381 \\
\hline 2 & 0.0124 & 0.0127 & 0.0119 & 0.0093 & 0.0095 & 0.0080 \\
\hline 3 & 0.0040 & 0.0040 & 0.0036 & 0.0014 & 0.0015 & 0.0012 \\
\hline 4 & -0.0038 & -0.0037 & -0.0041 & -0.0039 & -0.0039 & -0.0039 \\
\hline 5 & -0.0342 & -0.0244 & -0.0479 & -0.0242 & -0.0229 & -0.0271 \\
\hline Q1-Q5 & 0.0671 & 0.0576 & 0.0802 & 0.0580 & 0.0542 & 0.0652 \\
\hline \multicolumn{4}{|c|}{ Panel G. Market timing of funds with $0<\beta<1$} & \multicolumn{3}{|c|}{ Panel H. Stock picking of funds with $0<\beta<1$} \\
\hline 1 & 0.0351 & 0.0294 & 0.0419 & 0.0458 & 0.0436 & 0.0496 \\
\hline 2 & 0.0106 & 0.0109 & 0.0101 & 0.0137 & 0.0141 & 0.0123 \\
\hline 3 & 0.0035 & 0.0034 & 0.0043 & 0.0031 & 0.0029 & 0.0038 \\
\hline 4 & -0.0018 & -0.0020 & -0.0012 & -0.0038 & -0.0038 & -0.0041 \\
\hline 5 & -0.0290 & -0.0245 & -0.0362 & -0.0324 & -0.0261 & -0.0388 \\
\hline Q1-Q5 & 0.0641 & 0.0539 & 0.0781 & 0.0782 & 0.0697 & 0.0884 \\
\hline \multicolumn{4}{|c|}{ Panel I. Market timing of funds with $\beta<0$} & \multicolumn{3}{|c|}{ Panel J. Stock picking of funds with $\beta<0$} \\
\hline 1 & 0.0074 & 0.0052 & 0.0113 & 0.0081 & 0.0073 & 0.0145 \\
\hline 2 & 0.0001 & 0.0001 & 0.0000 & 0.0012 & 0.0012 & 0.0011 \\
\hline 3 & -0.0001 & -0.0001 & 0.0000 & 0.0003 & 0.0003 & 0.0002 \\
\hline 4 & -0.0001 & -0.0001 & -0.0001 & -0.0003 & -0.0003 & -0.0003 \\
\hline 5 & -0.0029 & -0.0023 & -0.0038 & -0.0040 & -0.0027 & -0.0099 \\
\hline Q1-Q5 & 0.0102 & 0.0075 & 0.0152 & 0.0121 & 0.0099 & 0.0244 \\
\hline
\end{tabular}

Notes: Table 7 is divided into 10 panels and shows the manager performance (panels A and B) and manager skills (panels C-J) in five quintiles for the period analyzed (December 2002-September 2015), in booms and in recessions. Quintile 1 represents the highest value and quintile 5 the lowest value. We report average manager CAPM alphas (panel A), fourfactor alphas (Panel B), market timing (panel C), stock picking (panel D), market timing and stock-picking of managers running funds with betas higher than one (panels $\mathrm{E}$ and $\mathrm{F}$ ), market timing and stock-picking of managers running funds with betas between zero and one (panels $\mathrm{G}$ and $\mathrm{H}$ ), and market timing and stock-picking of managers running funds with betas lower than zero (panels I and J). The last row of each panel is the difference between first and fifth quintiles.

funds), and managers of funds with aggressive betas (panel F, Table 7) present higher selectivity in booms (except 1st quintile managers), which are both contrary to prior results. It is also noticeable that funds with defensive betas (panel H, Table 6) are more skilled in booms (except the second quintile funds), contrary to the results of Table 2, panel B, suggesting a remarkable influence of the second quintile funds in the pool results. Finally, the panel $\mathrm{J}$ of Tables 6 and 7 shows that top quintile funds and managers with inverse fund betas achieve better 
stock-picking in crises, and the remaining funds do so in booms. Although the picking-quintile analysis shows higher stock-picking evidence in recessions for top funds and managers, skillful managers present better results in both booms and crises, while bottom funds are not able to select stocks correctly in any period.

Overall, Tables 6 and 7 show that performance and skill measures increase monotonically from bottom to top quintile funds. Timing is generally higher in recessions, and picking in booms, although these patterns are not so obvious in the manager analysis. Additionally, top funds and managers present correct timing and stock-picking at the same time; that is, they do not specialize because they are able to develop both skills. On the other hand, some of the intermediate-bottom funds only develop one skill correctly, showing some specialization. Finally, the worst funds and managers do not present any skill, suggesting that the non-specialization provokes poor skills in unskillful or limited-skill managers. This evidence is consistent with our hypothesis (Section 3.2) that managers with limited skills should specialize because diversification might derive in incorrect skills.

\subsection{Performance and skill persistence}

In the previous section, we observe that the top (bottom) funds and the skillful (unskilled) managers develop positive (negative) skills in booms and recessions; however, we do not know whether the same funds and managers are the best and the worst in different periods and in different skills. In this section, we study whether funds and managers are persistent over time, distinguishing skill from luck.

We sort pension funds and managers into five quintiles, based on fund/manager performance, fund/manager market timing and fund/manager stock-picking skills, and build contingency tables to compare winners (top quintile) and losers (bottom quintile) between two different periods (the entire period analyzed, booms or recessions). Tables 8 and 9 collect the results and show the percentage of funds (Table 8) and managers (Table 9) that remain in a quintile or change.

In both tables, panel A examines whether top/bottom funds (Table 8) and skillful/unskilled managers (Table 9) in the general ranking (considering the entire period analyzed) persist in their positions during booms and recessions (panels A1 and A2), and whether top/bottom funds and managers are the same in booms and recessions (panel A3). Comparing both tables, we observe persistence of the best and worst performers (CAPM alpha) in the general ranking (considering the entire period analyzed); specifically, $80 \%$ (66.67\%) of the best funds (managers) and $80 \%(77.78 \%)$ of the worst funds (managers) remain in the best and worst positions in booms (panel A1), respectively. Nonetheless, only 40\% (11.11\%) of the best funds (managers) persist as winners in recessions (panel A2), showing fewer skillful managers during recessions. Moreover, panel A2 shows higher persistence in worst managers (77.78\%, Table 9) than in bottom funds $(20 \%$, Table 8$)$ in recessions, which reflects that bottom funds tend to fire worst managers during crises. Panel A3 shows that 20\% (33.33\%) of winner funds (managers) in booms are winners in recessions, and $40 \%(55.56 \%)$ of losers persist in last positions during both booms and recessions.

Second, the four-factor fund alpha persistence results (Table 8) show that $20 \%$ and $60 \%$ of the best funds in the general ranking are also best funds in booms and recessions, respectively (panels A1 and A2), and 40\% of best funds in booms are also best funds in recessions (panel A3). We do not find persistence between losing funds in the general ranking and booms, $40 \%$ of losers in the general ranking are losers in recessions, and $20 \%$ of worst funds in booms are also losers in recessions. 
Table 8. Fund persistence analysis.

\begin{tabular}{|c|c|c|c|c|c|c|c|c|c|c|c|c|}
\hline & \multicolumn{5}{|c|}{ Panel A. Performance, portfolio beta, market timing and stock-picking persistence } & \multicolumn{3}{|c|}{ Panel A2. Period analyzed and recessions } & \multicolumn{4}{|c|}{ Panel A3. Booms and recessions } \\
\hline & WW & WL & LW & LL & WW & WL & LW & LL & WW & WL & LW & LL \\
\hline CAPM alpha & $80 \%$ & $0 \%$ & $0 \%$ & $80 \%$ & $40 \%$ & $20 \%$ & $20 \%$ & $20 \%$ & $20 \%$ & $20 \%$ & $20 \%$ & $40 \%$ \\
\hline 4-Factor alpha & $20 \%$ & $0 \%$ & $0 \%$ & $0 \%$ & $60 \%$ & $20 \%$ & $20 \%$ & $40 \%$ & $40 \%$ & $40 \%$ & $20 \%$ & $20 \%$ \\
\hline Market timing & $0 \%$ & $40 \%$ & $0 \%$ & $0 \%$ & $80 \%$ & $20 \%$ & $0 \%$ & $100 \%$ & $0 \%$ & $40 \%$ & $0 \%$ & $60 \%$ \\
\hline Stock picking & $80 \%$ & $0 \%$ & $0 \%$ & $80 \%$ & $40 \%$ & $60 \%$ & $0 \%$ & $40 \%$ & $20 \%$ & $80 \%$ & $40 \%$ & $20 \%$ \\
\hline
\end{tabular}

Panel B. Persistence between market timing and stock-picking abilities in different periods

Panel B1. Timing in booms and picking in recessions

Panel B2. Timing in recessions and picking in booms

\begin{tabular}{lcccccc}
\hline WW & WL & LW & LL & WW & WL & LW \\
$0 \%$ & $40 \%$ & $40 \%$ & $20 \%$ & $0 \%$ & $60 \%$ & $40 \%$
\end{tabular}

Panel C. Persistence between market timing and stock-picking abilities in the same periods

\begin{tabular}{|c|c|c|c|c|c|c|c|}
\hline \multicolumn{4}{|c|}{ Panel C1. Timing and picking in booms } & \multicolumn{4}{|c|}{ Panel $\mathrm{C} 2$. Timing and picking in recessions } \\
\hline WW & WL & LW & LL & WW & WL & LW & LL \\
\hline $20 \%$ & $0 \%$ & $40 \%$ & $40 \%$ & $20 \%$ & $20 \%$ & $20 \%$ & $40 \%$ \\
\hline
\end{tabular}

Notes: Table 8 is divided into three panels and shows the contingency tables resulting from classifying funds as winners or losers, in two periods. Each panel displays the percentage of winners-winners (WW), winners-losers (WL), losers-winners (LW), and losers-losers (LL) between the two periods. Panel A shows the persistence of funds in performance (CAPM alpha, 4-Factor alpha) and skills (market timing and stock-picking) between the entire period analyzed and booms (panel A1), the period studied and recessions (panel A2), and booms and recessions (panel A3). Panel B shows whether some funds are good at both skills in different periods, testing whether the same funds exhibit stock-picking in booms and market timing in crises (panel B1) and vice versa (panel B2). Panel C shows whether some funds present both skills in the same periods; specifically, in booms (panel C1) and recessions (panel C2). 
Table 9. Manager persistence analysis.

\begin{tabular}{|c|c|c|c|c|c|c|c|c|c|c|c|c|}
\hline \multicolumn{13}{|c|}{ Panel A. Manger performance, portfolio beta, market timing and stock picking } \\
\hline & \multicolumn{4}{|c|}{ Panel A1. Period analyzed and booms } & \multicolumn{4}{|c|}{ Panel A2. Period analyzed and recessions } & \multicolumn{4}{|c|}{ Panel A3. Booms and recessions } \\
\hline & WW & WL & LW & LL & WW & WL & LW & LL & WW & WL & LW & LL \\
\hline Capm alpha & $66.67 \%$ & $0.00 \%$ & $0.00 \%$ & $77.78 \%$ & $11.11 \%$ & $0.00 \%$ & $0.00 \%$ & $77.78 \%$ & $33.33 \%$ & $0.00 \%$ & $11.11 \%$ & $55.56 \%$ \\
\hline 4f alpha & $66.67 \%$ & $0.00 \%$ & $0.00 \%$ & $77.78 \%$ & $33.33 \%$ & $0.00 \%$ & $0.00 \%$ & $55.56 \%$ & $11.11 \%$ & $11.11 \%$ & $11.11 \%$ & $44.44 \%$ \\
\hline Market timing & $66.67 \%$ & $0.00 \%$ & $11.11 \%$ & $55.56 \%$ & $44.44 \%$ & $11.11 \%$ & $0.00 \%$ & $66.67 \%$ & $22.22 \%$ & $22.22 \%$ & $22.22 \%$ & $22.22 \%$ \\
\hline Stock picking & $88.89 \%$ & $0.00 \%$ & $0.00 \%$ & $55.56 \%$ & $11.11 \%$ & $0.00 \%$ & $11.11 \%$ & $33.33 \%$ & $11.11 \%$ & $11.11 \%$ & $22.22 \%$ & $11.11 \%$ \\
\hline
\end{tabular}

Panel B. Manager persistence between market timing and stock-picking abilities in different periods

\begin{tabular}{lr}
\hline Panel B1. Timing in booms and picking in recessions & Panel B2. Timing in recessions and picking in booms \\
\hline
\end{tabular}

\begin{tabular}{lccccccc}
\hline WW & WL & LW & LL & WW & WL & LW & LL \\
$22.22 \%$ & $22.22 \%$ & $55.56 \%$ & $11.11 \%$ & $0.00 \%$ & $11.11 \%$ & $11.11 \%$ & $22.22 \%$
\end{tabular}

Panel C. Manager persistence between market timing and stock-picking abilities in the same periods

\begin{tabular}{lccccccc}
\hline \multicolumn{4}{c}{ Panel C1. Timing and picking in booms } \\
\hline WW & WL & LW & LL & WW & WL & LW & LL \\
$0.00 \%$ & $66.67 \%$ & $22.22 \%$ & $22.22 \%$ & $44.44 \%$ & $22.22 \%$ & $33.33 \%$ & $44.44 \%$
\end{tabular}

Notes: Table 9 is divided into three panels and shows the contingency tables resulting from classifying managers as winners or losers, in two periods. Each panel displays the percentage of winners-winners (WW), winners-losers (WL), losers-winners (LW), and losers-losers (LL) between the two periods. Panel A shows the persistence of fund managers in performance (CAPM alpha, 4-Factor alpha) and skills (market timing and stock-picking) between the entire period analyzed and booms (panel A1), the period studied and recessions (panel A2), and booms and recessions (panel A3). Panel B shows whether some managers are good at both skills in different periods, testing whether the same managers exhibit stock-picking in booms and market timing in crises (panel B1) and vice versa (panel B2). Panel C shows whether some managers present both skills in the same periods; specifically, in booms (panel C1) and recessions (panel C2). 
With regard to the four-factor manager alpha persistence (Table 9), we find persistence in winner and loser managers in all panels. Nonetheless, the persistence of winners in the period analyzed considerably decreases in recessions $(33.33 \%$, panel A2) as well as from booms to recessions (11.11\%, panel A3). These figures exhibit problems among the best managers to follow as winners during crises.

Additionally, comparing Tables 8 and 9, we find higher performance persistence in loser managers than in loser funds, but lower persistence in winner managers than in winner funds (except from the period analyzed to boom), which confirms that funds frequently substitute managers (hiring good managers and dismissing poor performers) to maintain the fund in good ranking positions.

Market timing results show different conclusions between funds and managers. While fund results (Table 8) show no persistence between the general ranking and the boom ranking $(0 \%$ in panel A1), $66.67 \%$ and $55.56 \%$ of the best and worst timers in the period analyzed continued as best and worst timers in booms. These results are consistent with the lower and higher timing found for funds and managers in expansions. On the contrary, winner and loser funds in the general ranking are more persistent in recessions than managers (panel A2). In panel A3, we only find fund loser persistence (Table 8): 60\% of loser funds in booms are persistent losers in recessions.

The stock picking persistence (panels A1 and A2) shows persistence of winners and losers (funds and managers) in the general ranking and booms, but persistence is lower in recessions, especially for managers. Panel A3 shows absence of persistence between booms and recessions in both tables. This evidence suggests that many of the best (worst) pickers in booms are not the best (worst) pickers in crises, confirming distinctive selectivity skill with market conditions.

Prior results report higher evidence of market timing than picking in recessions and of stockpicking than timing in booms, but some of the top (bottom) funds and managers develop both skills correctly (incorrectly) in both periods. Consequently, we examine whether the same funds and managers exhibit both abilities in different periods; that is, stock-picking in booms and market timing in crises (panel B), or the same managers develop timing and picking in the same periods, that is, in recessions or booms, but not in different periods (panel C).

Panel B1 shows little evidence that timing winners in booms are picking winners in crises (0\% in funds and $22.22 \%$ in managers), and 20\% (11.11\%) are fund (managers) timing losers in booms and picking losers in recessions. Panel B2 confirms the absence of winners' persistence between different periods ( $0 \%$ of timing winners in recession are picking winners in booms), and $60 \%(22.22 \%)$ of fund (manager) timing losers in recessions are picking losers in booms, showing some persistence among losers. These findings show that those managers who pick stocks correctly in expansions do not time the market in recessions, and vice versa. This result is contrary to Kacperczyk et al. (2014), possibly because the same managers present both skills in the same periods, rather than in different periods.

Panel C shows some persistence for both skills in the same periods, especially among funds. Specifically, in expansions (panel C1), $20 \%$ of the best funds in timing are also winners in stockpicking, $40 \%(22.22 \%)$ of fund (manager) losers in timing are also losers in stock-picking. In crises (panel C2), 20\% (44.44\%) of funds (managers) are winners in both abilities, and 40\% $(44.44 \%)$ of funds (managers) are losers in both skills. These figures show more fund persistence in booms and that managers are more persistent in crises. These differences may be explained by manager replacements; for example, we suppose that one fund is timer and picker winner in two boom periods and the fund has been run by two different managers in these periods, 
so the fund is persistent winner in booms, but the managers may not be persistent winner in booms.

Furthermore, panels B and C show that only some of the best funds and managers exhibit both skills in the same periods, and few of them present both skills in different periods; revealing that not all funds and managers have time-varying skills.

\subsection{The (non-)specialization cost results}

Prior results (Tables 2, 3, 6, 7) show that managers present lower results in one skill if managers present both skills. These results suggest that skill diversification requires attention to several assignments and the success in both tasks may imply lower achievement in one skill, especially whether managers feel overwhelming and/or possess limited skills. Indeed, Tables 6 and 7 show that the worst funds and managers do not present skills. Therefore, whether managers with limited skills try to develop both skills, they may fail in the attempt and not develop any skill. In this case, managers should try to specialize in the task that they do better.

In this section, analyzing the components of expression (4), we study the results of skill diversification and specialization. In particular, we examine whether the funds/managers that presents both skills are better in one, the result of non-specialization in the worst funds, unskillful and limited-skill managers, and whether some limited-skill managers specialize. Tables 10 and 11 show the results for funds and managers, respectively.

Table 10 (panel A) shows three types of funds: good funds (positive picking and timing), intermediate funds (only one skill) and bad funds (no skills), and Table 11 (panel A) shows three types of managers: skillful (positive skills), unskillful (negative picking and timing), and limited-skill managers (positive picking and negative timing or vice versa).

Table 10. The (non-)specialization cost in pension funds.

Panel A: Skill measures considering specialization or diversification

\begin{tabular}{|c|c|c|c|c|c|c|}
\hline & \multicolumn{2}{|c|}{ Period analyzed } & \multicolumn{2}{|c|}{ Booms } & \multicolumn{2}{|c|}{ Recessions } \\
\hline & Picking & Timing & Picking & Timing & Picking & Timing \\
\hline Correct timing and picking skills & 0.0289 & 0.0258 & 0.0232 & 0.0214 & 0.0444 & 0.0380 \\
\hline Incorrect timing and picking skills & -0.0236 & -0.0286 & -0.0130 & -0.0244 & -0.0458 & -0.0380 \\
\hline Correct timing, incorrect picking & -0.0399 & 0.0303 & -0.0273 & 0.0282 & -0.0642 & 0.0345 \\
\hline Incorrect timing, correct picking & 0.0460 & -0.0406 & 0.0398 & -0.0316 & 0.0592 & -0.0605 \\
\hline
\end{tabular}

Panel B: Cost of skill specialization/diversification

\begin{tabular}{lcrr}
\hline & Period analyzed & Booms & Recessions \\
\hline Correct timing and picking skills & 0.0547 & 0.0446 & 0.0824 \\
Incorrect timing and picking skills & -0.0522 & -0.0374 & -0.0838 \\
Correct timing, incorrect picking & -0.0096 & 0.0009 & -0.0297 \\
Incorrect timing, correct picking & 0.0054 & 0.0082 & -0.0013 \\
\hline
\end{tabular}

Notes: Table 10 is divided into two panels. Panel A shows the average skill results when funds present both skills, neither of them, or only one of them (correct timing or correct stock-picking) in the period analyzed, in booms and in recessions. Panel B shows the results of the first element of expression (4) to analyze whether fund diversification impacts negatively or positively on the stock-picking skill when funds present correct skills, the non-specialization cost of funds with incorrect skills, and the impact of skill specialization (correct timing or stock-picking). 
Table 11. The (non-)specialization cost of managers.

Panel A: Skill measures considering manager specialization or diversification

\begin{tabular}{lrrrrrr}
\hline & \multicolumn{2}{c}{ Period analyzed } & \multicolumn{2}{c}{ Booms } & \multicolumn{2}{c}{ Recessions } \\
\cline { 2 - 7 } & Picking & Timing & Picking & Timing & Picking & Timing \\
\hline Correct timing and picking skills & 0.0332 & 0.0242 & 0.0280 & 0.0202 & 0.0484 & 0.0361 \\
Incorrect timing and picking skills & -0.0290 & -0.0306 & -0.0164 & -0.0243 & -0.0463 & -0.0394 \\
Correct timing, incorrect picking & -0.0456 & 0.0378 & -0.0300 & 0.0335 & -0.0759 & 0.0462 \\
Incorrect timing, correct picking & 0.0572 & -0.0459 & 0.0522 & -0.0352 & 0.0693 & -0.0716 \\
\hline
\end{tabular}

Panel B: Cost of skill specialization/diversification

\begin{tabular}{lcrr}
\hline & Period analyzed & Booms & Recessions \\
\hline Correct timing and picking skills & 0.0574 & 0.0481 & 0.0846 \\
Incorrect timing and picking skills & -0.0596 & -0.0407 & -0.0857 \\
Correct timing, incorrect picking & -0.0078 & 0.0035 & -0.0297 \\
Incorrect timing, correct picking & 0.0113 & 0.0170 & -0.0023 \\
\hline
\end{tabular}

Notes: Table 11 is divided into two panels. Panel A shows the average skill results when managers develop both skills, neither of them, or only one of them (correct timing or correct stock-picking) in the period analyzed, in booms and in recessions. Panel B shows the results of the first element of expression (4) to analyze whether manager diversification impacts negatively or positively on the stock-picking skill when managers develop correct skills, the non-specialization cost of managers with incorrect skills, and the impact of skill specialization (correct timing or stock-picking) in terms of stock-picking.

Funds and managers with correct market timing and stock-picking skills are example of correct diversification and present higher stock-picking in all periods. Nonetheless, the achievement of timing supposes a considerable effort; affecting negatively the stock-picking skill since the first element of measure (4) in panel B is higher than the final picking score. Concerning funds and managers with incorrect skills, diversification is not the correct strategy for the worst funds and managers, and specialization might produce better result. In particular, the timing score of these funds and managers is less negative than they first element of expression (4) in panel B, so they might try to specialize in timing.

The correct timing and incorrect stock-picking of some funds and mangers evidence that limited-skill managers choose specialize in timing because they present advantage in this skill. Specifically, the first element of the picking score (panel B) is negative (whole period and recessions) or smaller than the timing score (booms), revealing poor selectivity skills, especially in crises. Lastly, the funds and managers that specialize in stock-picking display limited timing skills, so picking specialization is the correct strategy. Particularly, the first element of expression (4) is small (whole period and booms) or negative (crises), but the non-specialization in timing results in positive selectivity.

These results confirm that specialization for intermediate funds and managers with limited competences is the correct strategy, versus the diversification of unskillful and limited-skill managers who are not able to develop skills. Furthermore, we check (not reported ${ }^{6}$ ) that the funds and managers that diversify correctly are in top skill quintiles, the funds and managers that diversify incorrectly belong to bottom picking and timing quintiles, the managers with timing skills are in top-middle timing quintiles and bottom picking quintiles, and the managers with picking skills are in top-middle picking quintiles and bottom timing quintiles. 


\subsection{Performance-skill and risk-skill relations}

In this last section, we study the relationships between performance and skills, and between risk and skills at fund and manager levels. Tables 12 and 13 collect the results for fund and manager analyses, respectively. Panels A and B show the relationship between performance and skills, considering the CAPM and four-factor alphas as dependent variables, respectively. Since our skill measures are quarterly, quarterly alphas are obtained from daily data. Panel $\mathrm{C}$ shows the relationship results between fund betas and skills. ${ }^{7}$

Examining both tables, in panel A, we find a positive relationship between stock-picking abilities and fund/manager performance for the period analyzed; that is, the higher the stockpicking skill, the better the performance, and vice versa. Additionally, the fund analysis also shows this positive relationship during expansion periods (Table 12). The market timing skill does not influence the CAPM alpha, independently of the economic condition in both tables.

Table 12. Fund beta-skill and fund performance-skill relationships.

\begin{tabular}{|c|c|c|c|}
\hline & Period analyzed & Booms & Recessions \\
\hline \multicolumn{4}{|c|}{ Panel A. Relationship between CAPM alpha and skills } \\
\hline \multirow[t]{2}{*}{ Market timing } & 0.0314 & 0.0209 & 0.023 \\
\hline & $(0.97)$ & $(0.46)$ & $(0.49)$ \\
\hline \multirow[t]{2}{*}{ Stock picking } & $0.0474 *$ & $0.0728 *$ & 0.0212 \\
\hline & $(1.77)$ & $(1.67)$ & $(0.51)$ \\
\hline \multirow[t]{2}{*}{ Constant } & $-0.0056^{* * *}$ & $-0.003 *$ & $-0.0136 * * *$ \\
\hline & $(-2.91)$ & $(-1.65)$ & $(-4.64)$ \\
\hline$R^{2}$ within & 0.0061 & 0.0054 & 0.011 \\
\hline$R^{2}$ between & 0.1641 & 0.2937 & 0.0214 \\
\hline$R^{2}$ overall & 0.0061 & 0.0092 & 0.0029 \\
\hline \multicolumn{4}{|c|}{ Panel B. Relationship between 4-factor alpha and skills } \\
\hline \multirow[t]{2}{*}{ Market timing } & $0.0757 *$ & 0.0531 & 0.0916 \\
\hline & $(1.92)$ & $(1.16)$ & $(1.23)$ \\
\hline \multirow[t]{2}{*}{ Stock picking } & $0.0649 *$ & $0.1131 * * *$ & 0.0343 \\
\hline & $(1.82)$ & $(2.61)$ & $(0.52)$ \\
\hline \multirow[t]{2}{*}{ Constant } & $0.0096 * * *$ & $0.0097 * * *$ & $0.0087 *$ \\
\hline & $(5.34)$ & $(5.75)$ & $(1.89)$ \\
\hline$R^{2}$ within & 0.0095 & 0.0152 & 0.0069 \\
\hline$R^{2}$ between & 0.1951 & 0.2524 & 0.1069 \\
\hline$R^{2}$ overall & 0.0117 & 0.0223 & 0.012 \\
\hline \multicolumn{4}{|c|}{ Panel C. Relationship between fund beta and skills } \\
\hline \multirow[t]{2}{*}{ Market timing } & 0.1216 & $0.4129 * *$ & -0.1319 \\
\hline & $(0.97)$ & $(2.08)$ & $(-0.99)$ \\
\hline \multirow[t]{2}{*}{ Stock picking } & -0.0373 & -0.0997 & -0.0707 \\
\hline & $(-0.33)$ & $(-0.52)$ & $(-0.63)$ \\
\hline \multirow[t]{2}{*}{ Constant } & $0.8604 * * *$ & $0.8566 * * *$ & $0.8753 * * *$ \\
\hline & $(68.94)$ & $(56.96)$ & $(57.87)$ \\
\hline$R^{2}$ within & 0.0042 & 0.0222 & 0.0031 \\
\hline$R^{2}$ between & 0.0055 & 0.0089 & 0.1943 \\
\hline$R^{2}$ overall & 0.0016 & 0.014 & 0.021 \\
\hline
\end{tabular}

Notes: Table 12 shows the regression results of the relationships between fund performance (CAPM and 4-factor alphas) and fund skills (panels A and B), and the relationships between fund betas and fund skills (panel C) during the period analyzed, in boom and in recession periods. Z-statistics are reported in parentheses. All models are estimated by random effects. *, **, and *** indicate significance at the $10 \%, 5 \%$, and $1 \%$ level, respectively. 
Panel B displays different results between funds and managers. Table 12 shows positive picking-performance and timing-performance relationships for the period analyzed; that is, the fund performance is higher if funds present skills. This table also shows performance improvement with correct stock-picking abilities in booms. This evidence is consistent with the initial results of better stock-picking in expansions (Table 2). On the other hand, panel B of Table 13 shows a positive relationship between market-timing and manager performance in the period analyzed and booms, consistent with the higher manager timing found in booms. Additionally, this panel shows a positive relationship between manager performance and picking skills in recessions.

Panel $\mathrm{C}$ shows a positive relationship between market-timing skills and fund /manager-fund betas in expansions. Better market timers increase exposure to the market in boom periods (the fund betas are higher) and decrease it in recessions, although the market timing coefficients

Table 13. Manager beta-skill and manager performance-skill relationships.

\begin{tabular}{|c|c|c|c|}
\hline & Period analyzed & Booms & Recessions \\
\hline \multicolumn{4}{|c|}{ Panel A. Relationship between CAPM alpha and skills } \\
\hline \multirow[t]{2}{*}{ Market timing } & 0.0216 & -0.0122 & 0.0396 \\
\hline & $(0.7)$ & $(-0.26)$ & $(0.93)$ \\
\hline \multirow[t]{2}{*}{ Stock picking } & $0.0492 * *$ & 0.0607 & 0.0327 \\
\hline & (2.03) & (1.58) & (1) \\
\hline \multirow[t]{2}{*}{ Constant } & $-0.0071 * * *$ & $-0.005 * * *$ & $-0.0122 * * *$ \\
\hline & $(-4.91)$ & $(-2.77)$ & $(-4.2)$ \\
\hline$R^{2}$ within & 0.0081 & 0.011 & 0.0188 \\
\hline$R^{2}$ between & 0.019 & 0.0235 & 0.0017 \\
\hline$R^{2}$ overall & 0.0089 & 0.0112 & 0.0083 \\
\hline \multicolumn{4}{|c|}{ Panel B. Relationship between 4-factor alpha and skills } \\
\hline \multirow[t]{2}{*}{ Market timing } & $0.1568 * * *$ & $0.327 * * *$ & 0.0531 \\
\hline & $(4.19)$ & $(7.53)$ & $(0.83)$ \\
\hline \multirow[t]{2}{*}{ Stock picking } & 0.046 & 0.0055 & $0.0876^{*}$ \\
\hline & (1.59) & $(0.15)$ & $(1.83)$ \\
\hline \multirow[t]{2}{*}{ Constant } & 0.0027 & $0.0034 * *$ & $0.0124 *$ \\
\hline & $(0.49)$ & (2) & $(1.67)$ \\
\hline$R^{2}$ within & 0.0457 & 0.1773 & 0.0275 \\
\hline$R^{2}$ between & 0.1895 & 0.2158 & 0.0122 \\
\hline$R^{2}$ overall & 0.0377 & 0.1825 & 0.0255 \\
\hline \multicolumn{4}{|c|}{ Panel C. Relationship between fund beta and skills } \\
\hline \multirow[t]{2}{*}{ Market timing } & $0.1916^{* *}$ & $0.4371 * * *$ & -0.0913 \\
\hline & (2) & $(3.08)$ & $(-0.74)$ \\
\hline \multirow[t]{2}{*}{ Stock picking } & -0.015 & -0.1586 & -0.0475 \\
\hline & $(-0.2)$ & $(-1.37)$ & $(-0.52)$ \\
\hline \multirow[t]{2}{*}{ Constant } & $0.8556 * * *$ & $0.8704 * * *$ & $0.8439 * * *$ \\
\hline & $(51.85)$ & (61.87) & (37.64) \\
\hline$R^{2}$ within & 0.0134 & 0.0614 & 0.003 \\
\hline$R^{2}$ between & 0.0076 & 0.0388 & 0.0729 \\
\hline$R^{2}$ overall & 0.0028 & 0.0345 & 0.0132 \\
\hline
\end{tabular}

Notes: Table 13 shows the regression results of the relationships between manager performance (CAPM and 4-factor alphas) and manager skills (panels A and B), and the relationships between manager fund betas and manager skills (panel C) during the period analyzed, in boom and in recession periods. Z-statistics are reported in parentheses. All models are estimated by random effects. *,**, and *** indicate significance at the $10 \%, 5 \%$, and $1 \%$ level, respectively. 
are insignificantly negative in crises. This evidence is consistent with correct timing and active strategies; specifically, the higher manager idiosyncratic risk in booms translates into higher manager performance in booms (panel B, Table 13). Finally, fund betas are not influence by stock-picking abilities.

\section{Conclusions}

Pension funds are professionally managed products, so pension fund participants are especially concerned about the performance and management of their investments. Performance traditionally decomposes into stock-picking and market timing abilities; that is, the skill to invest/disinvest in the correct assets and at the correct time.

The financial literature presents mixed evidence about these skills, finding conflicting results. One possible explanation for these results is provided by Kacperczyk et al. (2014), who indicate that skills depend on economic conditions. In this paper, we examine whether the skills of pension funds and managers vary with economic conditions because the long-term nature of pension funds induces a lower adjustment frequency of the portfolio allocations and, as a consequence, economic cycles may affect pension fund skills to a lesser extent.

We execute the same analysis from fund and manager perspectives in order to analyze whether skills reside in funds or managers and control for manager substitutions. Since funds frequently experience manager replacement, the fund level study shows the fund trajectory, and the manager analysis allows us to examine the skill and performance of specific individuals over time. This study, as far as we are aware, is the first work that implements this dual analysis.

Our initial results show that fund and managers vary their skills with economic conditions. Pension funds and managers present higher stock-picking ability during expansions, and higher market timing during recessions. We then study whether the top and bottom funds and managers develop different behavior (performance and skills) with economic conditions. Our results show that the top funds and managers always outperform, while the bottom funds and managers always underperform. Furthermore, top funds and managers exhibit both skills, while bottom funds and managers display neither, in both booms and recessions.

A deeper analysis shows certain skill persistence and not all funds and managers have the ability to adapt to market conditions. Specifically, some of the top (bottom) funds and managers are the best (worst) in both abilities in the same periods, but not in different periods. Furthermore, performance persistence is higher in winner funds and loser managers. These results show that funds substitute frequently managers (hiring good managers and dismissing poor performers) to maintain the funds in good positions.

The different skills under changing economic conditions display a skill specialization; however, the top (bottom) funds/managers presents both (none) skills and simultaneously, so skill specialization is applied by managers with limited skills. Diversification requires attention to many and different functions and unskillful managers find difficult to achieve both skills, so specialization may be the solution for their bad results. Finally, we observe a positive relationship between performance and skills.

Our findings are important for pension fund participants, beneficiaries and managers. Participants can identify those managers who create value and adapt their skills to market conditions, taking less time in their decision-making, and managers can learn much about their own abilities and, in the process, try to improve them. Additionally, participants can identify funds with better trajectories; specifically, our results show similar results between funds and managers but, many results are better at fund level, showing that funds periodically substitute managers trying 
to provide the best results to participants over time; that is, fund skills are the labor of several managers through time.

\section{Disclosure statement}

No potential conflict of interest was reported by the authors.

\section{Funding}

This work was supported by University of Zaragoza and Fundación Ibercaja [JIUZ-2015-SOC-01].

\section{Notes}

1. Data obtained from the Spanish Association of Investment and Pension Funds (INVERCO): ww.inverco.es.

2. The Spanish market capitalization is obtained from World development indicators database: http://data.worldbank. org/data-catalog/world-development-indicators.

3. The three management groups, from a total of 50 groups, are: Caixa Bank, BBVA Bank and Santander Bank, according to INVERCO (www.inverco.es).

4. Data available on the website of Fama and French: http://mba.tuck.dartmouth.edu/pages/faculty/ken.french/ data_library.html. We clarify that the Spanish factors are not available and there is no Spanish country portfolio information for market, size, and momentum factors.

5. The models of Tables 4 and 5 are estimated with fixed effects. We also estimate these models with random effects and compare both estimations with the Hausman test. The Hausman test results reject the null hypothesis, so we estimate the models with fixed effects.

6. These results are available upon request.

7. The models of Tables 12 and 13 are estimated with random effects. We also estimate these models with fixed-effects and compare both estimations applying the Hausman test. The Hausman test results do not allow us to reject the null hypothesis (random effect is the correct specification). In a second step, we compare the random effects and OLS estimations with the Breusch-Pagan Lagrange multiplier (LM) for random effects. The LM test results reject the null hypothesis of zero variance across funds, so we apply random effects. These results are available upon request.

\section{References}

Abdel-Kader, M. G., and K. Y. Qing. 2007. "Risk-Adjusted Performance, Selectivity, Timing Ability and Performance Persistence of Hong Kong Mutual Funds.” Journal of Asia-Pacific Business 8 (2): 25-58.

Alda, M., L. Ferruz, and F. Muñoz. 2010. "Do Pension Funds Managers Display Stock-Picking and Market Timing Ability? Evidence from the United Kingdom and Spain.” Spanish Journal of Finance and Accounting 39: 349-365.

Alda, M., L. Ferruz, and L. Gallagher. 2013. "Performance of Spanish Pension Funds: Robust Evidence from Alternative Models." Applied Financial Economics 23: 297-314.

Ammann, M., and A. Zingg. 2008. "Investment Performance of Swiss Pension Funds and Investment Foundations." Swiss Journal of Economics and Statistics 144 (II): 153-195.

Avramov, D., and R. Wermers. 2006. "Investing in Mutual Funds When Returns are Predictable.” Journal of Financial Economics 81: 339-377.

Becker, C., W. Ferson, D. Myers, and M. Schill. 1999. "Conditional Market Timing with Benchmark Investors.” Journal of Financial Economics 52: 119-148.

Bhardwaj, R., and L. Brooks. 1993. "Dual Betas from Bull and Bear Markets: Reversal of the Size Effect.” Journal of Financial Research 16: 269-283.

Blake, D., B. Lehmann, and A. Timmermann. 1999. “Asset Allocation Dynamics and Pension Fund Performance." Journal of Business 72: 429-461.

Bollen, N., and S. Busse. 2001. "On the Timing Ability of Mutual Fund Managers.” Journal of Finance 56 (3): $1075-$ 1094.

Bollerslev, T., R. F. Engle, and J. M. Wooldridge. 1988. "A Capital Asset Pricing Model with Time-Varying Covariances." Journal of Political Economy 96: 116-131. 
Boney, V., G. Comer, and L. Kelly. 2005. "High Quality Bond Funds: Market Timing Ability and Performance.” Working Paper. http://papers.ssrn.com.

Busse, J. A. 1999. "Volatility Timing in Mutual Funds: Evidence from Daily Returns." Review of Financial Studies 12: 1009-1041.

Carhart, M. 1997. “On Persistence in Mutual Fund Performance.” The Journal of Finance 52 (1): 57-82.

Chen, Y., W. E. Ferson, and H. Peters. 2010. "Measuring the Timing Ability and Performance of Bound Mutual Funds." Journal of Financial Economics 98 (1): 72-89.

Christensen, M. 2005. “Danish Mutual Fund Performance-Selectivity, Market Timing and Persistence.” Working Paper of Aarhus School of Business. http://papers.ssrn.com/.

Christopherson, J., W. Ferson, and D. Glassman. 1998. "Conditioning Manager Alphas on Economic Information: Another Look at the Persistence of Performance.” Review of Financial Studies 11: 111-142.

Clinebell, J., J. Squires, and J. Stevens. 1993. "Investment Performance over Bull and Bear Markets: Fabozzi and Francis Revisited." Quarterly Journal of Business and Economics 32: 14-25.

Coggin, T. D., F. J. Fabozzi, and S. Rahman. 1993. "The Investment Performance of U.S. Equity Pension Fund Managers: An Empirical Investigation.” The Journal of Finance 48 (3): 1039-1055.

Daniel, K., M. Grinblatt, S. Titman, and R. Wermers. 1997. "Measuring Mutual Fund Performance with Characteristic based Benchmarks." Journal of Finance 52 (3): 1035-1058.

Edelen, R. M., and J. B. Warner. 1999. "Why Are Mutual Fund Flow and Market Returns Related? Evidence from High-frequency Data.” Financial Institution Centre 99-01.

Elton, E. J., M. J. Gruber, and C. R. Blake. 2012. “An Examination of Mutual Fund Timing Ability Using Monthly Holdings Data." Review of Finance 16 (3): 619-645.

Evans, M. D. D. 1994. "Expected Returns, Time-Varying Risk, and Risk Premia.” Journal of Finance 49: 655-679.

Fabozzi, F., and J. Francis. 1977. "Stability Tests for Alphas and Betas over Bull and Bear Market Conditions." Journal of Finance 32: 1093-1099.

Fabozzi, F., and J. Francis. 1979. "Mutual Fund Systematic Risk for Bull and Bear Markets: An Empirical Examination." Journal of Finance 34: 1243-1250.

Fama, E., and K. French. 1993. "Common Risk Factors in the Returns on Stocks and Bonds." Journal of Financial Economics 33 (1): 3-56.

Ferson, W., and M. Quian. 2004. "Conditional Performance Evaluation Revisited.” Research Foundation Monograph of the CFA Institute (formerly, AIMR) ISBN 0-943205-69-7, 84 pages.

Ferson, W., and R. Schadt. 1996. "Measuring Fund Strategy and Performance in Changing Economic Conditions." Journal of Finance 51: 425-461.

Fung, H. G., X. Xu, and J. Yau. 2002. "Global Hedge Funds: Risk, Return and Market Timing.” Financial Analysts Journal 58 (6): 19-30.

Glassman, D. A., and L. A. Riddick. 2006. "Market Timing by Global Fund Managers.” Journal of International Money and Finance 25: 1029-1050.

Glode, V. 2011. “Why Mutual Funds Underperform?” Journal of Financial Economics 99: 546-559.

Graham, J., and C. R. Harvey. 1996. "Market Timing Ability and Volatility Implied in Investment Newsletters' Asset Allocation Recommendations." Journal of Financial Economics 42: 397-421.

Grinblatt, M., and S. Titman. 1993. "Performance Measurement without Benchmarks: An Examination of Mutual Fund Returns." Journal of Business 66: 47-68.

INVERCO. 2014. "Las Instituciones de Inversión Colectiva y los Fondos de Pensiones Informe 2014 y Perspectivas 2015." www.inverco.es.

Jiang, G. J., T. Yao, and T. Yu. 2007. "Do Mutual Funds Time the Market? Evidence from Portfolio Holdings." Journal of Financial Economics 86 (3): 724-758.

Kacperczyk, M., S. V. Nieuwerburgh, and L. Veldkam. 2011. "Rational Attention Allocation over the Business Cycle." Working paper, New York University.

Kacperczyk, M., S. V. Nieuwerburgh, and L. Veldkam. 2014. "Time-Varying Fund Manager Skill.” The Journal of Finance 69 (4): 1455-1484.

Kacperczyk, M., and A. Seru. 2007. "Fund Manager Use of Public Information: New Evidence on Managerial Skills." Journal of Finance 62: 485-528.

Kizys, R., and C. Pierdzioch. 2011. "The Changing Sensitivity of Realized Portfolio Betas to U.S. Output Growth: An Analysis based on Real-Time Data." Journal of Economics and Business 63: 168-186.

Knigge, A., E. Nowak, and D. Schmidt. 2004. "On the Performance of Private Equity Investments: Does Market Timing Matter?” Journal of Financial Transformation 16 (April): 123-134. 
Koh, B. S., O. S. Mitchell, and J. Fong. 2010. “Collective Investments for Pension Saving: Lessons from Singapore's Central Provident Fund Scheme.” Pensions: An International Journal 15 (2): 100-110.

Kosowski, R. 2011. "Do Mutual Funds Perform When it Matters Most to Investors? U.S. Mutual Fund Performance and Risk in Recessions and Expansions." Quarterly Journal of Finance 1: 607-664.

Kostovetsky, L. 2010. "Brain Drain: Are Mutual Funds Losing Their Best Minds?” Working paper, University of Rochester.

Laplante, M. 2003. "Conditional Market Timing with Heteroskedasticity.” PhD diss., University of Washington.

Lee, S. L. 1999. "The Conditional Performance of UK Property Funds.” Paper presented Meeting Anual de la American Real Estate Society, Tampa, April 7-10.

Lewellen, J., and S. Nagel. 2006. "The Conditional CAPM does not Explain Asset-Pricing Anomalies." Journal of Financial Economics 82: 289-314.

Ley 8/1987. Ley 8/1987 de 8 de junio, de Regulación de los Planes y Fondos de Pensiones. Spanish legislation.

Mamaysky, H., M. Spiegel, and H. Zhang. 2008. "Estimating the Dynamics of Mutual Fund Alphas and Betas." Review of Financial Studies 21: 233-264.

Merton, R. C., and R. D. Henriksson. 1981. "On Market Timing and Investment Performance II: Statistical Procedures for Evaluating Forecasting Skills." The Journal of Business 54: 363-534.

Moskowitz, T. J. 2000. "Discussion of Mutual Fund Performance: An Empirical Decomposition into Stock-Picking Talent, Style, Transactions Costs, and Expenses." Journal of Finance 55: 1695-1703.

Neuhierl, A., and B. Schlusche. 2011. "Data Snooping and Market-Timing Rule Performance." Journal of Financial Econometrics 9 (3): 550-587.

OECD. 2014. Pension Markets in Focus. OECD. www.oecd.org.

Raju, B. P., and K. M. Rao. 2009. "Market Timing Ability of Selected Mutual Funds in India: A Comparative Study." The Icfai Journal of Applied Finance 15 (3): 34-48.

Real Decreto 304/2004. Real Decreto 304/2004 de 20 de febrero, por el que se aprueba el Reglamento de Planes y Fondos de Pensiones. Spanish legislation.

Real Decreto Legislativo 1/2002. Real Decreto Legislativo 1/2002 de 29 de noviembre, por el que se aprueba el Texto Refundido de Regulacion de los Planes y Fondos de Pensiones. Spanish legislation.

Schmidt, D., E. Nowak, and A. Knigge. 2004. "On the Performance of Private Equity Investments: Does Market Timing Matter?" Paper presented at the EFMA 2004 Basel Meeting.

Sialm, C., L. T. Starks, and H. Zhang. 2015. "Defined Contribution Pension Plans: Sticky or Discerning Money?” The Journal of Finance 70 (2): 805-838.

Spiceland, D., and J. Trapnell. 1983. "The Effect of Market Conditions and Risk Classifications on Market Model Parameters." The Journal of Financial Research 6: 217-222.

Thomas, A., and I. Tonks. 2001. "Equity Performance of Segregated Pension Funds in the UK." Journal of Asset Management 1 (4): 321-343.

Treynor, J., and K. Mazuy. 1966. “Can Mutual Funds Outguess the Market?” Harvard Business Review 44: 131-136.

Woodward, G., and R. Brooks. 2009. “Do Realized Betas Exhibit Up/Down Market Tendencies?” International Review of Economics and Finance 18: 511-519.

Woodward, G., and R. Brooks. 2010. "The Market Timing Ability of Australian Superannuation Funds: Nonlinearities and Smooth Transition Models." In The Risk Modeling Evaluation Handbook: Rethinking Financial Risk Management Methodologies in the Global Capital Markets, edited by Gregoriou, G., C. Hoppe, and W. Carsten, 59-73. USA: MacGraw-Hill. http://monash.edu/research/explore/en/publications/the-market-timing-ability-of-australiansuperannuation-funds-nonlinearities-and-smooth-transition-models(b7ad7ea8-367e-4b65-90de-7e48892c99bd). html.

Zambrana, R., and F. Zapatero. 2015. "A Tale of Two Types: Generalists vs. Specialists in Mutual Funds Asset Management.” Working paper. http://www.novasbe.unl.pt/images/novasbe/files/Research_Papers/zapatero.pdf. 


\section{Pension fund manager skills over the economic cycle: the (non-)specialization cost}

\section{Mercedes Alda}

To cite this article: Mercedes Alda (2016): Pension fund manager skills over the economic cycle: the (non-)specialization cost, The European Journal of Finance, DOI: 10.1080/1351847X.2016.1239585

To link to this article: http://dx.doi.org/10.1080/1351847X.2016.1239585

\section{舟 Published online: 03 Oct 2016.}

Submit your article to this journal $₫$

Q View related articles ¿

View Crossmark data ¿ 